\title{
The crisis in water supply: how different it can look through the lens of the human right to water?
}

\author{
A crise no abastecimento de água: como se mostraria \\ diferente se observada através da lente do direito \\ humano à água?
}

La crisis en el suministro de agua: ¿Cómo resultaría

diferente si vista a través del lente del derecho

humano al agua?

Léo Heller ${ }^{1}$

\footnotetext{
${ }^{1}$ Centro de Pesquisas René Rachou, Fundação Oswaldo Cruz, Belo Horizonte, Brasil.

Correspondence L. Heller

Centro de Pesquisas René

Rachou, Fundação Oswaldo

Cruz.

Av. Augusto de Lima 1715,

Belo Horizonte, $M G$

30190-002, Brasil.

heller@cpqrr.fiocruz.br
}

The human right to safe drinking water and sanitation was explicitly recognized through resolutions passed by the UN General Assembly 1 in July 2010 and Human Rights Council 2 in September 2010, with strong support from the Brazilian government. The General Assembly's resolution states explicitly that this right "is essential for the full enjoyment of life and all human rights", which can be understood in conjunction with other definitions of human rights, for example, that "all human rights are universal, indivisible and interdependent and interrelated" 3. This last statement means that access to safe drinking water and sanitation should be considered a fundamental precondition for the "enjoyment of several human rights, including the rights to education, housing, health, life, work..." and should guarantee gender equality and non-discrimination ${ }^{4}$. Specifically, the Committee on Economic, Social, and Cultural Rights acknowledged that the right to health extends to the underlying determinants of health, including access to safe drinking water and sanitation 5 . The combination of these concepts results in citizens' entitlement to these rights (including the right to claim them through the legal system) and obligations on the part of national states and service providers.

Achieving this human right to water and sanitation (RtWS) means ensuring water with availability, accessibility, quality, safety, and affordability, meeting the requirements of acceptability, dignity, and privacy.

As Brazil now faces a dramatic crisis in water supply, severely affecting its most populated, urbanized, and industrialized region, the RtWS framework can serve as an invaluable perspective for assessing the situation.

First, assessing the roots of the current crisis, if water providers had respected RtWS principles, the current climatic oscillation would not have turned into a water scarcity for human consumption. Key RtWS principles include "maximum available resources" and the need for appropriate planning to ensure access to water. In addition, retrogression in access violates the right to water. We can safely state that, if adequate planning for the water supply in the affected localities, amphasizing water security, had been properly adopted, the problem would not exist in its current intensity. When simulating future scenarios, appropriate strategic planning must take into account climatic situations with low probability of occurrence, among other variables 6 . Leading contemporary trends in water planning argue in favor of strategic, creative, and participatory planning, and that adaptive water systems should be designed with the capacity for social learning $7,8,9$. If the water planning process in Brazil had effectively incorporated these prin- 
ciples, Brazilian cities would have increased their resilience to situations of water stress.

A second issue that deserves a look from the RtWS perspective is the set of measures planned or adopted to deal with the crisis. These measures should now be the main concern, since during any consumption restriction the most severely affected population groups are precisely the most vulnerable ones. Disadvantaged groups have fewer resources to deal with water scarcity due to their lower economic capacity, and are the most heavily impacted, especially from a health perspective. Vulnerable populations include not only the poor, such as slumdwellers, but also the elderly, children, homeless, disabled, prison inmates, and hospital patients and schoolchildren.

Brazil's current situation requires placing RtWS principles at the center of decision-makers' agenda. Water supply crisis management, through such measures as rationing, decreasing pressure in water mains, fines on high consumption, and campaigns against wastage should not assume that users will be impacted evenly. Tackling the crisis requires not only universal measures but also targeted ones, focusing on the most vulnerable groups in order to protect them from the effects of water restrictions and ensure the non-discrimination and non-retrogression principles of the RtWS framework.

The scientific literature has adequately explained and extensively reported on the health effects of inadequate water supply and sanitation. However, retrogression in access to water caused by restrictive measures challenges our ability to predict the types and intensity of hazard to which the population will be exposed.

The environmental classification of waterrelated diseases considers four distinct groups of transmission mechanisms: (1) water-borne, when pathogens are transmitted through contaminated drinking water; (2) water-washed, transmitted by inadequate domestic and personal hygiene; (3) water-based, caused by pathogens that spend part of their life cycle in an aquatic animal, with schistosomiasis as the most common example; and (4) insect vectors that breed in or bite near water 10,11. A similar classification was developed for excreta-related infections 12, which could also be used to address the situation, considering that water scarcity sewage disposal (but the latter is beyond the scope of this article).

The water-related classification can be used as a framework for assessing potential impacts of water scarcity. The transmission of diseases through mechanisms 1, 2, and 4 could increase when restrictive measures are applied. However, unlike usual situations, the impacts are occurring in a "transient" state, not in a "stable" state, where the population has already experienced a long period of adaptation to water supply with adequate quantity and quality and has already incorporated specific routine daily hygienic practices. This could be an exacerbating factor for stable state impacts.

Through the first mechanism, it is plausible to expect different reasons for deterioration of drinking water quality. First, operation of the water distribution network with intermittent presence of water is a well-known situation in which water can become contaminated by infiltration of pathogens from the soil into the pipes, caused by the negative pressure inside the latter. Second, household water storage in improvised tanks (in order to face that periods lack of supply), together with handling water from the tanks, clearly threatens the water's quality.

The second mechanism seems obvious, considering that households will receive less water in the period. The literature provides ample evidence that hygienic practices are heavily affected in such cases ${ }^{13}$. Importantly, the practice of levying fines for water consumption that exceeds historical averages (adopted or planned by some providers) can result in water consumption short of essential needs in some cases.

These first two mechanisms could facilitate the spread of various infectious and parasitic diseases, with viruses, bacteria, and protozoa as the etiological agents.

Regarding the fourth mechanism, current restrictions on water consumption and the population's resulting skepticism towards the regularity of the public water supply are a powerful combination for household hoarding of water, sometimes stored in uncovered or precariously covered tanks and with unsafe water handling. Water storage provides an effective breeding place for insect vectors. Interestingly, restrictions on water consumption frequently occur in the rainy season, as a preventive measure, precisely when urban dengue outbreaks are most common. New water management practices caused by such restrictions can actually aggravate transmission of the dengue and Chikungunya viruses.

The RtWS approach provides a different perspective for examining these forecasts. Health risks are not distributed evenly or randomly across the population. Wealthier groups can more easily protect themselves from the crisis by paying for water trucks, drilling wells, or buying bulk amounts of bottled water 14, among other measures. RtWS requires that the public sector protect the most vulnerable, minimizing the social impacts of the crisis. In the health sector, the 
water supply crisis challenges epidemiological and environmental surveillance to step up mobilization and focus on water-related exposures suffered by vulnerable populations groups.

Finally, Brazil's current water crisis highlights the importance of two other RtWS principles: transparency and participation. Government authorities and water utility companies should be as transparent and accountable as possible to keep the population informed of the situation and its likely developments. Water restrictions should not be seen as merely "technical" decisions. Actually, different solutions can be considered to deal with the water shortage, and such decision-making is not neutral, entailing social consequences. Democratic decision-making with participation by the most affected communities is the best way to minimize the impacts of the crisis, especially on health.
1. United Nations. General Assembly Resolution A/ RES/64/292. The human right to safe drinking water and sanitation. http://www.un.org/en/ga/ search/view_doc.asp?symbol=A/RES/64/292.

2. Human Rights Council Resolution A/HRC/ RES/15/9. Human rights and access to safe drinking water and sanitation. http://daccess-ods. un.org/TMP/5257991.55235291.html.

3. Vienna Declaration and Programme of Action. Adopted by the World Conference on Human Rights in Vienna on 25 June 1993. http://www.ohchr.org/ EN/ProfessionalInterest/Pages/Vienna.aspx.

4. UN Office of the High Commissioner for Human Rights; UN Habitat; World Health Organization. The right to water. Fact Sheet n. 35. http://www. ohchr.org/EN/PublicationsResources/Pages/Fact Sheets.aspx.

5. Committee on Economic, Social and Cultural Rights. General Comment n. 15 on the right to the highest attainable standard of health. http:// tbinternet.ohchr.org/_layouts/treatybodyexternal/ Download.aspx?symbolno=E\%2fC.12\%2f2002\%2f1 $1 \&$ Lang=en .

6. Heller L, Rodrigues LA, Silveira RB. Scenarios for environmental sanitation in Brazil. Water Policy 2014; 16:501-19.

7. Pahl-Wostl C. Towards sustainability in the water sector: the importance of human actors and processes of social learning. Aquat Sci 2002; 64:394411.

8. Pahl-Wostl C, Jeffrey P, Isendahl N, Brugnach M. Maturing the new water management paradigm: Progressing from aspiration to practice. Water Resources Management 2011; 25:837-56.

9. Shammout MW, Shatanawi M, Naber S. Participatory optimization scenario for water resources management: a case from Jordan. Water Resources Management 2013; 27:1949-62.

10. White GF, Bradley DJ, White AU. Drawers of water: domestic water use in East Africa. Chicago: University of Chicago Press; 1972.

11. Ensink JHJ, Cairncross S. Abastecimiento de agua, saneamiento, higiene y salud pública. In: Heller L, editor. Agua y saneamiento: en la búsqueda de nuevos paradigmas para las Américas. Washington DC: Organización Panamericana de la Salud; 2002. p. 1-24.

12. Feachem RG, Bradley DJ, Garelick H, Mara DD. Sanitation and disease: health aspects of excreta and wastewater management. Chichester: John Wiley \& Sons; 1983.

13. Bartram J, Cairncross S. Hygiene, sanitation, and water: forgotten foundations of health. PLoS Med 2010; 7:e1000367.

14. Queiroz JTM, Doria MF, Rosenberg M, Heller L, Zhouri A. Perceptions of bottled water consumers in three Brazilian municipalities. J Water Health 2013; 11:520-31.

Submitted on 02/Mar/2015

Approved on 04/Mar/2015 